\title{
Chapter 7 \\ Growing Up to Belong Transnationally: Parent Perceptions on Identity Formation Among Latvian Emigrant Children in England
}

\author{
Daiga Kamerāde and Ieva Skubiṇa
}

\subsection{Introduction}

Family emigration patterns from Latvia have changed over time. In the early 2000s it was common for parents in Latvia to emigrate to Western European countries but to leave their children, at least temporarily, to be brought up by grandparents and other relatives while they searched for a job and to establish themselves in the new home country (Broka 2009; Trapenciere 2012). Since 2008 an increasing number of parents who have now settled in their new home country have decided to bring up their children themselves. Others now emigrate together with their children (Kamerāde 2017). These children (the so-called '1.5 generation' child migrants) are thus the children born in their country of origin but being brought up in emigration (Rumbaut 1976; Rumbaut and Ima 1988).

The aim of this paper is to examine the perspective of parents on the formation of national and transnational identity among the 1.5 generation migrant children children born in Latvia but growing up in England - and to factors affecting this. In particular, we focus on language that is central to the formation of children's national identity, and especially the retention of the mother tongue and the learning of the language of the host country.

The focus in this paper is on emigrants from Latvia living in England, which is the main destination country for the majority of migrants from Latvia (OECD 2014). As Rumbaut and Ima (1988) have emphasised, the 1.5 generation migrants are different in terms of their national identity from their parents. The identity of their parents - the first-generation migrants - was formed in their country of origin

D. Kamerāde $(\bowtie)$

University of Salford, Greater Manchester, UK

e-mail: d.kamerade-hanta@salford.ac.uk

I. Skubina

Institute of Philosophy and Sociology, University of Latvia, Riga, Latvia

e-mail: ieva@petijums.lv 
and they themselves decided to migrate. The 1.5 generation migrants who have directly experienced life in both countries are also different from the secondgeneration migrants born in the new host country who have received information about their 'homeland' primarily from their parents' stories and memories.

Because of the wide availability of social media, cheap flights and free movement within the EU, it has become much easier to maintain links with the country of origin than it was even a generation ago. Therefore, the formation of transnational identity among children of recent migrants might be significantly different from the experiences of children of previous generations. However, the current understanding of the development of transnational identity is based mostly on research involving the previous generations of migrants and might not fit the experiences of the more recent migrant children. Studies focusing on migrants from Latvia are not an exception to this pattern.

This article enriches the information provided by other scholars who have analysed Latvian migrant national identity formation within the framework of transnationalism in both groups - among adults (Ķešāne 2011; Lulle 2011; Šūpule 2012) and children (Lulle and Klave 2015). Of particular relevance is an article by Cara (2015) on a study of Latvian diaspora children in English schools. The author used quantitative research methods to explain an alarming fact regarding children with English as a second language (Strand et al. 2015). Those children who used Latvian as a first language at home got lower grades in secondary school exams compared to other non-British children and those with English as their first language.

This article first reviews the literature on the 1.5 generation migrants and their specific characteristics, and analyses the main factors that help this group form a sense of belonging and transnational identity. Secondly, using semi-structured indepth interviews with the parents of 1.5 generation Latvian children currently living in England, their perceptions of the formation of transnational ties in those children are examined. This paper concludes with the implications of those findings for theory and policy making.

\subsection{Formation of Identity Among 1.5 Generation Migrants and Factors Affecting It}

Identity as a complex and constantly changing phenomenon (Burke 2006) refers to the way in which individuals perceive and define relationships with the world and how these relationships are developed (Norton 1997, 2000, 2013). Identity is a process, which is why it is perhaps more appropriate to talk about identification (Jenkins 2014). Individual identity is constructed during, and through, interaction with others (Jenkins 2014).

There is increasing agreement in the literature that national and ethnic identity is not monolithic and exclusive any more. It is possible that when living in a multinational and multi-cultural environment or in a new country, the national identity of 
the country of origin is supplemented with a new and additional national identity (Parpola 2004). Identity can also be constructed as a set of identities, each multifaceted, changing and developing in response to changing practices and experiences. Scholars argue that traditional, popular, high and post-modern cultures interact over the boundaries of time and space (Westin 2010). In this context, migration expands the field of identity. The period of nation-states has been replaced by a period of multi-culturalism where boundaries are easy to cross (Urry 2000). Therefore it is important to be aware that identities can reach far beyond the territory (Bauman and May 2001).

Transnational identity is one of the fundamental characteristics of international migration. It occurs in situations when migrants concurrently maintain relationships of high intensity and regularity with their country of origin and country of settlement (Vertovec 2009, 2010), and describes activities which involve regular, intensive and continuous social cross-border contacts. Portes et al. (1999) emphasise the significance of continuity and intensity of contacts.

Transnationalism is also characterised by an imagined integrality with others in a similar situation; subjective feelings of belonging both 'here and there'; culture reproduction that involves combining different cultures and creating new hybrid cultures and political participation across the borders, e.g. expressing an opinion, lobbying or participating in non-governmental organisations (Vertovec 2010).

According to scholars of transnationalism, if migrants gradually reduce their contacts with, and activities related to, their country of origin, they could not be perceived as experiencing transnationalism. Transnationalism differentiates the recent generation of migrants from previous generations. Their social networks and their economic, political and cultural activities, as well as their lifestyle models, often include both countries (Kivisto 2001).

Many studies have focused on the formation of identity, including transnational identity among immigrants (Block 2009; Byrd Clark 2009). Several studies have examined the experiences of 1.5 generation migrants (e.g. Benesch 2008; Kim and Duff 2012; McKay and Wong 1996; Yuzefova 2012). However, there are still very few studies that focus on the formation of transnational identity among the recent 1.5 generation migrants from Eastern Europe and the Baltic States.

The origins of the concept of ' 1.5 generation migrants' - children born in their country of origin but who emigrated during their childhood - can be traced back to Rumbaut (1976) who identified 1.5 generation migrants in the USA as children born in Cuba who migrated while still young with their parents to the USA.

Scholars emphasise that the transnational identity formation in 1.5 generation migrants is different from the identity formation in first generation migrants who emigrated as adults, and also second generation migrants, that is, those children born to migrant parents who have settled into a new country. At the same time, the research emphasises that the younger a 1.5 generation child is, the more similar their experiences of adaption and integration into a new host country will be to second generation children. According to Awokoya (2012), the younger a child is when they arrive in a new host country, the faster their integration proceeds - and the more likely that their choice of language will be that of the new country rather than the 
mother tongue. This is related to the child's limited proficiency in their mother tongue and their lack of personal experience of the home country and memories as evidence of immersion in the culture. Other factors include their low level of socialisation in the society of the country of origin, and their active inclusion in the education system that is the most institutionalised institution of their new country of settlement (Awokoya 2012; Lulle and Klave 2015).

Asher and Case (2008) argue that the concept ' 1.5 generation migrants' reflects the situation of the generation of migrants who are 'in between' - a hybrid generation which does not exclusively identify with or belong to either their country of origin or the country of settlement. The authors agree with the view of Goldschmidt and Miller (2005) that the 1.5 generation belongs to two cultural fields: the field of national identity, values and attitudes of their country of origin, usually experienced at home, and the cultural field of their new country, experienced at the school they attend. As a result they face a challenge: the need to adapt to the culture of their country of settlement while still being integrated into the culture of their country of origin (Berry 1997). Children who were brought up in a pluralistic society often become 'bi-cultural'. They apply values, attitudes and behavioural models that are characteristic of both their country of origin and country of settlement (Phinney and Rotheram 1987). The 1.5 generation children and youths often function 'in between' two cultures, as it were: they speak two languages and balance between two sets of values (Asher and Case 2008; Carhill et al. 2008; Singhal 2004).

Other authors emphasise the dominance of the language and national identity of the new country of settlement in the national identities of 1.5 generation migrant children, and the supporting role of education in the formation of a transnational identity. Socialisation through education facilitates stronger ties with the new culture. Thus Roberge (2003) argues that if the 1.5 generation migrants emigrated when they were young, they have been socialised in the school abroad and have learned the language of the country of settlement, which can become dominant. Consequently, even if they identify with their language of origin, they might still use the language of the country of settlement more.

Yet the 1.5 generation migrants face challenges that are unique to their generation. During the critical stages of the development of their own personality and identity, they have to develop a sense of belonging.

It can be argued that the 1.5 generation migrants choose their national identity. They define it and present it to others through their language. Research shows that national identity and language are strongly related and that identity is constructed through language, as emphasised by Byrd Clark (2012). The development of a national identity occurs in parallel with social integration and the acquisition of language. By learning the language of their country of settlement, migrants can internalise its values, traditions and culture more successfully, thus increasingly becoming an integrated member of that society and sharing a collective identity.

Research shows that other people perceive and identify the 1.5 generation migrants depending on how these migrants identify themselves and which language they use. Often these young people feel closer to their new friends and schoolmates 
from the country of settlement than with their contemporaries from their country of origin. As they speak the language, these children and young people increasingly identify themselves with their country of residence and its culture (Heller 1987; Liang 2006).

Yet knowing and using two languages is also associated with some communication difficulties. Pavlenko (2011) suggests that migrant children who have to use two languages - one at home and another at school - often have difficulties expressing themselves verbally. A perfect knowledge of language is not sufficient; part of the process of choosing words and formulating one's thoughts is dependent on significantly deeper emotional intelligence skills (Yang 2010). Consequently, migrant children may not be able to express aspects of the inner worlds that characterise their identity if they do not know how to describe it; either in their mother tongue or in the new language. Huss (2008) argues that the adaptation to new language occurs at the expense of losing one's mother tongue. The 1.5 generation migrants choose mostly to use the language of their new country of settlement as the dominant language. For example, Cummins (2000) observed that for young migrant children English becomes their dominant language in day-to-day conversations within 2 years of arrival, and the dominant language in learning and education within 4-7 years. This is accompanied by the loss or significant reduction of the mother tongue.

According to previous research, the parental effect on mother tongue usage policy at home is one of the most important factors to maintain the national identity of the country of origin. Often parents want their children to retain their mother tongue and the values, traditions and customs of their country of origin (Phinney et al. 2001). Also, parents manifesting their belonging to a certain culture can influence the values, attitudes and perception of the national identity of their children (Phinney et al. 2001). Unfortunately, national identity and belonging create conflicts between parents and children, for example if the children want to adapt more quickly and develop stronger ties to the culture of the country of settlement (Rosenthal 1987). On the other hand, migrant parents often want their children to excel in their education, which requires a good knowledge of the language of the country of settlement. Such conflicting parental messages create frustration and challenges for the 1.5 generation migrants.

Rosenthal (1987) has also observed an interesting cross-over effect: while the 1.5 generation children become only partial users of their mother tongue, their parents often remain only partial users of English. Often, while parents talk at home in their mother tongue, their children respond to them in English (Kasnitz et al. 2009).

Therefore, this paper aims to investigate how the parents of 1.5 generation children from Latvia see the formation of transnational identity among their children. It focuses in particular on the retention and development of the languages that children use at home and at school, and it questions whether we can talk about transnationalism in relation to the 1.5 generation migrants from Latvia. Are they truly 'transnational'? That is, are they maintaining and developing language ties both to their country of origin and the country of settlement? 


\subsection{Methods}

In order to investigate parents' perspectives on the formation of transnational identity among 1.5 generation migrants we used semi-structured interviews $(n=16)$ with parents of children who were born in Latvia but now live in England. The aim of the interviews was to investigate how emigrant families who want to retain their links with Latvia facilitate their children's ties with their country of origin. All names have been changed.

Participants for the interviews were selected using four criteria. Firstly, we focused on the most recent waves of emigration, in other words, those families that left Latvia after 2000. Secondly, in order to be able to investigate how the transnational identity of children develops over time, we selected only those families who had lived in England for at least 3 years. Thirdly, only families that had at least one child born in Latvia living with them in England were selected. Finally, families who were determined to maintain their links to Latvia were selected. This criterion was fulfilled by conducting interviews with parents who took their children on a regular basis (at least once a month) to Latvian supplementary schools in England. These schools are considered to be a significant agent in preserving the Latvian language, culture and national identity of the diaspora (Lulle and Klave 2015).

Potential participants were informed about the aims of the project. Most of the interviews were conducted either at the supplementary school while a participant's children were engaged in learning activities or at their home. In nearly all cases both parents in the two-parent families in the sample were available for the interview. When selecting research participants, we aimed to achieve diversity in the sample in terms of the household composition. The sample included four single parent and 12 two-parent families. The number of children per family varied between one and four and the age of children varied between 1 and 16 years. In terms of occupational status, approximately one third of the sample worked in a professional role, one third in administrative and sales jobs and one third in semi-skilled or unskilled sectors.

To analyse the interviews, we used a thematic coding approach. First we identified the units of analysis, then grouped them according to themes (Strauss and Corbin 1998). The results of the study presented in this paper identify tendencies in transnationalism that might be common to a broader range of Latvian emigrants and their children, and possibly similar trends are likely to be observed in similar contexts.

\subsection{Findings}

It should be noted that in The Emigrant Communities of Latvia survey parents with children mentioned that in general they wanted their children to preserve the Latvian language and thus their sense of national belonging to Latvians and Latvia. The data of The Emigrant Communities of Latvia survey show that the vast majority (85\%) 
of those Latvian emigrants with children who spoke Latvian in their family while living in Latvia continue to do so when living in the UK. Most parents (70\%) also pointed out that it was important for them that their children were either fluent in the Latvian language (50\%) or at least understood it $(20 \%)$. For a fairly large number of emigrants - a little more than a quarter (27\%) - it did not matter if their children were able to communicate in the Latvian language.

At the same time, there is a reverse tendency for Latvian emigrants to identify themselves with the current home country, and not with Latvia and Latvians. According to the UK Population Census 2011, out of 6088 children under the age of 18 living in the UK with at least one parent whose national identity is Latvian, almost half the children or their parents $(n=2978)$ identified the child's national identity as one of the UK identities (British, English, Welsh, Scottish, Northern Irish, Cornish). Slightly more than a third of the respondents $(\mathrm{n}=2126)$ noted that their national identity was Latvian, while $3 \%$ expressed a dual identity of both the UK and Latvia and 13\% indicated "other identities" (ONS 2015). These statistics demonstrate that the number of emigrant children identifying with the new home country is gradually increasing.

The findings of this qualitative research suggest that the formation of 'belonging' and 'transnational identity' is particularly shaped by two main factors: parental strategies in dealing with the use of two or more languages in everyday communication and the child's first experiences at school and of learning the English language.

\subsubsection{Parental Influences on the Formation of Transnational Identity in Children}

Although this study restricted itself to families determined to maintain their ties with their country of origin, only a few of them said they insisted on speaking Latvian at home as an affirmation of belonging to Latvia and 'Latvians'. This was despite the difficulties their children experienced in maintaining their mother tongue. For example, Maria and Peter who have three children and have lived in England for 4.5 years insist that only Latvian is spoken at home:

At home nobody speaks any other language [than Latvian]. We are Latvians. [..] Sometimes the children sign in English. [..] The oldest son sometimes does not know how to say something in Latvian, so he says it in English, but very rarely - just a word or so.

This is one example of a family in which the parents are determined to maintain their own national identity and that of their children, and they see language as a very important part of maintaining and confirming this identity.

Like other Latvian migrant families with this strong sense of national belonging, Maria and Peter are critical of families that do not use Latvian at home:

I know a family that have a Latvian child - David - who does not speak Latvian. I do not want my child to speak English at home; we will never speak English at home. He [our son] 
does not have a choice because nobody will speak with him differently. My brother lives in Ireland. Seven or eight years already, I don't know. [...] and that mother [her brother's partner] really wants them all to be Irish.

Migrant parents therefore have the complex task of persuading their children to speak Latvian in everyday life and maintaining a sense of belonging to Latvia, while also helping them learn English and develop a sense of belonging to England, to help the children form a transnational identity.

Research participants also observed that as their children's use of English increased in everyday communication, even those born in Latvia slowly forgot their mother tongue, adapted English grammar in Latvian or even refused to use Latvian at home, especially if corrected when they made mistakes. One mother, Alise, who has a daughter and a son and has lived in England for 4 years, told this story about her son:

He knows that he is a Latvian, that he lives in England. [... Once he hung a note on his door: 'Do not come into my room. I do not understand Latvian'. That was a while ago. It was quite terrible: he was very, very angry about something. I think he didn't understand one word and somebody laughed about it or something, and that hurt him very much, I think. After that event Latvian for him is a little bit ...' [related to negative experiences and he does not use it as often].

Some respondents report incidents when their children have asked them not to speak Latvian when their friends are around because they feel ashamed. Maria mentioned that 'Sometimes at school I feel that the older [boy] is a bit ashamed. He says: "Do not speak to me in Latvian. My schoolmates are listening." Liang (2006) and Heller (1987) explain this as the tendency of migrant children to distance themselves from their mother tongue in order to assimilate into their new community. The findings from this study indicate that such tendencies can also be found among the 1.5 generation migrant children from Latvia.

Sometimes maintaining the Latvian part of their children's transnational identity is motivated by the instrumental interests of the parents. Some parents emphasise that their main motivation of retaining a certain level of Latvian language skills is not simply to maintain a sense of national belonging, but because of more rational factors. The parents themselves find it easier to speak in Latvian and also they want their children to be able to communicate with their grandparents and other relatives back in Latvia.

Mass media and the use of social media play an important part in the formation of national identity among migrant children. Research shows that using various information sources and media in their native language positively influences the maintenance and development of the language of the country of origin, and their ties with it (Benesch 2008; Kivisto 2001). Some of the parents in the sample have attempted to immerse their children in the Latvian information field: they download and buy animation films, books and magazines in Latvian or ask relatives from Latvia to send them. However, they have observed that the children have to be encouraged repeatedly to use them. 
There is also an age correlation. The younger the children were when they arrived in England, the more passive their use of Latvian media was. However, this study finds that despite parental efforts, children might not use these outlets, and consequently these sources might play a limited role in the formation of transnationalism.

Most parents participating in this study emphasised their support for both their children's integration into the local community and for maintaining their Latvian language and national identity. Thus, it could be argued, they were supporting the formation of their children's transnational identity. At the same time parents also expressed concerns about their loss of the Latvian language.

The interviews suggest that parents have used different strategies and methods to help their children learn English; for example, involving children in after-school clubs and using support available from their school. Some families began to talk to their children in English, especially when noticing that they are experiencing difficulties with English spellings or pronunciation. For example, Rita and Andris, who have two children and have lived in England for 8 years, admitted that:

In our family we speak in mixed languages - both English and Latvian [...] When he [the child] began his schooling, he didn't know English at all, so I started to speak English at home to help him so that when he goes to school he understands something, at least. Now as a result he speaks more English than Latvian.

This example indicates that parental support for learning English in the form of using English at home can foster either the formation of a transnational identity or the national identity of the host country, although parents also acknowledge that after a while they realise that actively helping their children learn English has had a negative effect on maintaining and developing their mother tongue of Latvian (as cautioned by Pavlenko 2011; Yang 2010).

Ansis, who had lived with his partner and child in England for 4 years, observed that their mother tongue is becoming their daughter's second language because everyday experiences at school and with friends happened in English, and therefore they were often discussed in English at home:

Our daughter learned two languages in parallel: actually, she learned more English than Latvian, and therefore she has no strong grounding in Latvian. That is a bit of a problem. It would have been better, I think, if she would have had a strong foundation in Latvian, although it is difficult to tell. At home we speak Latvian. Our daughter has a problem if she wants to tell us about what she does at school or with her friends, because that happens in English and many things related to it are in English. She does not know enough Latvian words to say it in Latvian.

Parents themselves also acknowledge that sometimes they do not know the Latvian words for new toys or games. Increasingly, therefore, English enters communication between parents and children.

These findings are similar to those of Pavlenko (2011) that children develop their vocabulary in the language of the country of settlement and do not seek new words to describe their experiences in their mother tongue. This could be especially common among children who emigrated while still very young, indicating that even if a 
child forms a transnational identity his or her connections with the country and language of origin could weaken over time.

\subsubsection{First Experiences at School and Learning the English Language as Factors Influencing the Formation of Transnational Identity}

The interview data suggest that first experiences at an English school play a crucial role in learning English and successfully adapting to and integrating into the new country of settlement.

Anna, a divorced mother who has lived in England for 5 years, has two underage children and one adult daughter. Her daughter was 14 when they arrived in England. She shared an experience of her daughter's successful adaptation to school and acquisition of the English language, emphasising a migrant-friendly and supportive environment at the school in England her children attended:

My daughter was very happy. From the first day she was excited that everybody was greeting her, asking 'What is your name, where are you from?' and hugging her. She said the attitude and the relationships were so different from when she went to school in Latvia, where either nobody speaks to each other or talks about each other behind their backs. Her English was not good, but she was diligent and adapted [that is, she learned English and did well in the school].

Similar positive experiences were reported by Marta, a mother of two children, who had separated from her partner. She had lived in England for 8 years and emphasised her daughter's openness to change that helped her integrate into the school successfully, despite an initial lack of English language skills:

We never had any problems at school. She adapted within the first two weeks. I said to the teacher: 'If there are any problems, call me!' [...] She did not know any English at all, but she adapted. Seven years old, ideal, no problems at all. [...] And after three months she knew English so well that I was sitting and thinking "I lived here for how many years? ... four? $\ldots$ and I don't know it so well.

In contrast, Maria and Peter, who had lived with their three children in the United Kingdom for 4.5 years, acknowledged that their first few weeks in the country were difficult for their son. He was five when he started at school:

Our child had many more problems that we did, at the beginning. He didn't speak at all. [..] He had to go to school three days after our arrival. For the first year, he didn't know English. [..] Everywhere there were unfamiliar people, unfamiliar faces. I taught him a few words: what to say if he is in pain or needs to go to the toilet, but it was very hard for him at the beginning. He was five years old. The teacher said that he only began to speak English after a year or so. He just kept silent. He made some friends after a year....very slowly.

This example indicates a slower and more challenging process of learning English as part of the formation of a transnational identity. Later in the interview, 
Maria and Peter explained that, despite these initial difficulties, their son eventually became fluent in English. He is now using both Latvian and English when communicating with them and his siblings at home.

The interview data thus indicate that schooling experiences in the new country of settlement are important for forming a transnational identity, acquiring the language of the new host country and forming a sense of belonging and social integration. These findings are in line with other studies that also found that the first experiences in the new country of settlement - and experiences at school in particular - significantly affect the formation of identity and belonging among 1.5 generation migrants (Awokoya 2012). As Awokoya's study was conducted in a different social context (involving 1.5 generation Nigerian migrant children and youths) the similarities in the findings indicate that the role of school experiences in the process of transnational identity formation could be significant in a variety of social contexts in terms of language and belonging.

The findings also uncovered the first signs of the cross-over effect described by Rosenthal (1987). Marta's daughter learned the language of the host country faster than her mother, which might indicate that transnational identity is formed faster in child migrants than in migrant parents.

\subsubsection{Interaction with Other Latvian Children in Emigration and Transnational Identity Formation}

Migrant supplementary schools play an important role in forming and maintaining a Latvian identity and ties with Latvia as part of a transnational identity. Migrant supplementary schools are usually organised and run by parents themselves on a voluntary basis and are open once or twice a month on Saturdays or Sundays. The services offered by these schools vary depending on the location, available resources and vision of the founders of the school. These schools are an opportunity for Latvian migrant children and parents to meet other children and to learn about Latvian history and traditions. However, according to the official data, only a relatively small proportion of migrants with children attend such schools (Kārkliņa and Kamerāde 2016; NIPSIPP 2015). Several parents said that supplementary schools are not a priority for them. If children happen to have other activities at that time or a school is too far away, they do not attend them.

The opinions and experiences of parents whose children do attend these schools differ as to how they can help them form transnational identities. This may depend on which school their child attends or on the parents' own expectations of what the school should or should not be offering.

Some parents welcome the school's role in teaching language and traditions, but do not like it becoming a play school. While the original focus of the school was on Latvian history and traditions, if it becomes more engaged in organising entertain- 
ment activities and events the parents say its influence on maintaining national identity decreases.

Parents like Rita and Andris say they have seen children in Latvian supplementary schools speaking English among themselves, and they are critical:

We attend a Latvian supplementary school in [a certain city] and keep in touch with one family who live in [name of city]. I don't know about [how much] learning [is done] but [it's good for the kids] to meet and hear Latvian, to learn ... just to communicate]. Although I have to say most children that come here [to the supplementary school] do not speak Latvian. They speak English to each other.

Some research participants were sceptical about the long-term effects of Latvian supplementary schools in maintaining Latvian language and identity. They say these schools are more oriented towards pre-school and primary school age children, while teenagers refuse to attend them because they find them 'boring'. This finding indicates that as children grow older the role of migrant supplementary schools diminishes as a factor affecting the formation of transnational identities.

Summer camps for diaspora children are often aimed at forming and maintaining Latvian identity and ties with Latvia. Inga is married with two children and has lived in England for 11 years. Like several other parents in the sample, she expressed concerns that these camps were not well suited to their needs because they were organised mostly when their children are still at school or when the parents themselves did not have holidays.

Some participants reported that, in contrast to what might be expected, communicating and interacting with other Latvian children living in emigration did not help the 1.5 generation to maintain their mother tongue. Parents often mentioned that Latvian children began to communicate with each other in English and that parents often had to remind them to speak Latvian. Alise, who had lived with her partner and two children in England for 4 years, noted:

We often have to remind them: "Speak to your sister and your cousin's children in Latvian". They prefer to speak English. They [can] speak Latvian, but they need reminding because they use English every day. Similarly the boy, my youngest brother, he is fifteen, he has a friend, also Latvian, but as soon as they begin to talk about school, they do not know how to say it. They don't know how to explain it in Latvian.

These findings are further confirmation that the language of the country of settlement becomes dominant in the identity of 1.5 generation children - transnational or otherwise. Their mother tongue becomes a second language, spoken by family and friends.

Similar tendencies of migrant children preferring the language of their country of settlement have been observed by Cummins (2000) and Huss (2008). To sum up, our interviews with parents suggest that 1.5 generation migrants from Latvia are on the path to become transnationals or what Yang (2010) describes as 'English dominant bilinguals', characterised by two intersected and mixed but still distinguishable language-based identities. 


\subsection{Discussion and Conclusions}

According to the literature, transnational identity is characterised by maintaining ties of high intensity and regularity with both the country of origin and the host country, including the retention of the mother tongue and the learning of the language of the country of settlement. The aim of this study has been to examine the parental perceptions of how these transnational ties - and especially the language ties - are developed and maintained in their children. This study questioned how the 1.5 generation migrant children from Latvia were maintaining and developing language ties both to their country of origin and the country of settlement. In particular, using in-depth interviews with 16 parents, this study focused on some of the factors affecting the formation of transnational identity, such as parental influences on language choices, a child's first experiences at school, their language use and their participation in supplementary schools and summer camps.

The results suggest that at least so far there is little evidence as to the development of a strong transnational identity among 1.5 generation migrant children from Latvia: that is, children born in Latvia who emigrated during their childhood. Instead this study observed a tendency towards integration and assimilation into the new host country, a tendency either facilitated by their parents or occurring despite their parents' efforts to maintain ties with Latvia.

Latvian 1.5 generation migrants have a tendency to become 'English-dominant bilinguals' (Yang 2010), who prefer to use English as their day-to-day communication language, often despite their parents asking them to use Latvian. Their use of language depends on the context they operate in. At home they often speak Latvian with their parents, while at school and in other situations they use English. Characteristically, in day-to-day communication Latvian is often replaced by English, a tendency also observed by Huss (2008). Initially, both languages are mixed into the same sentence. Later, even their thinking is formulated in English. Depending on the social situation, children pick and choose which part of their identity to express and present to the outside world. They may prefer to use Latvian and to be Latvian when talking to a grandmother, friends or relatives in Latvia. In turn they would use English to integrate and belong inside and outside the school and when spending time with friends, both Latvian and English, who speak English.

The sample for the present study was selected from parents whose children attend Latvian supplementary schools, on the assumption that this attendance indicated their commitment to retaining ties with Latvia and a Latvian identity. However, only a small number of the families in the sample insisted on the use of Latvian as the only language at home as a way of retaining Latvian as a language their children can speak. Most parents accepted the increasingly frequent use of English in the family, thus supporting the development of transnational identities where the English language becomes dominant. Taking into account the sample characteristics, this finding might seem puzzling or even contradictory. However, it might signal that parents are trying to balance the challenges presented by the process of 
integrating into the host country while retaining ties with the country of origin at the same time. By accepting the occasional use of English at home they help their children integrate into the host country. Taking them to a Latvian supplementary school, in theory at least, helps their children keep in touch with their Latvian identity and Latvia. In this way, the parents facilitate the formation of transnational identities.

Although parents have a strong influence on the formation of the identity of their children, and may have a general understanding of their experience, their knowledge of the nuances of this experience is likely to be limited. The question remains how these 1.5 generation migrant children see themselves and describe themselves in terms of national and transnational identity. Are they Latvians? Latvians living in England? English Latvians? Latvian-English? For now, the findings from this study suggest that the transnational identity of 1.5 generation Latvian migrant children is, over time, becoming dominated by the language of the new country of settlement.

As migration expands the field of identity these findings suggest that instead of migrant children developing a new additional, supplementary national identity alongside the national identity of their country of origin, instead the identity of the country of settlement becomes dominant.

The findings of this research supplement the results of previous studies and clarify directions for the improvement of the state's educational policies and the information that should be provided to parents of children in the diaspora.

Given that the Latvian diaspora in the United Kingdom is one of the largest, we must be aware that a significant proportion of Latvian migrants in the UK have lower qualifications, are employed in average and low-skilled jobs and are not always insured. They are more likely to be segregated and live in municipalities where the standards of education in schools are not always the highest - and they do not have the skills to search for better educational opportunities for their children (Cara 2015). In this context, it is an alarming fact that children who use Latvian as the first language at home get lower grades in secondary school exams compared with other non-British children and those with English as their first language (Cara 2015; Strand et al. 2015).

All this highlights the urgent need to educate parents about the advantages of dual language usage and on the positive impact on the child's development mother tongue preservation has (Margevica-Grinberga 2015).

This will help reduce parental frustration and motivate parents to organise themselves, such as to participate in the Latvian schools and in the community to help their children developing the transnational identity formed when migrants concurrently maintain relationships of high intensity and regularity with their country of origin and country of settlement.

\section{References}

Asher, C., \& Case, E. (2008). A generation in transition: A study of the usage and attitudes toward public libraries by generation 1.5 composition students. Reference \& User Services Quarterly, 47(3), 274-279. 
Awokoya, J. (2012). Identity constructions and negotiations among 1.5- and second-generation Nigerians: The impact of family, school, and peer contexts. Harvard Educational Review, 82(2), 255-281.

Bauman, Z., \& May, T. (2001). Thinking sociologically (2nd ed.). Oxford: Blackwell.

Benesch, S. (2008). Generation 1.5' and its discourses of partiality: A critical analysis. Journal of Language, Identity, and Education, 7(3-4), 294-311.

Berry, J. W. (1997). Immigration, acculturation, and adaptation. Applied Psychology, 46(1), 5-34.

Block, D. (2009). Second language identities. London: Continuum.

Broka, A. (2009). Impacts of labor migration on children left-behind in Latvia: The role of the state. Oslo: Oslo University College.

Burke, P. J. (2006). Identity change. Social Psychology Quarterly, 69(1), 81-96.

Byrd Clark, J. (2009). Multilingualism, citizenship, and identity: Voices of youth and symbolic investments in an urban, globalized world. London: Continuum.

Byrd Clark, J. (2012). Heterogeneity and a sociolinguistics of multilingualism: Reconfiguring French language pedagogy. Language and Linguistics Compass, 6(3), 143-161.

Cara, O. (2015). Diasporas bērnu mācību gaitas Anglijas skolās: kvantitatīvs skatīijums [quantitative look at children of diaspora in the schools of England]. In A. Lulle \& E. Klave (Eds.), Possibilities of development: Education of Latvian diaspora youth and children (pp. 241-258). Riga: University of Latvia press.

Carhill, A., Suarez-Orozco, C., \& Paez, M. (2008). Explaining English language proficiency among adolescent immigrant students. American Educational Research Journal, 45(4), 1155-1179.

Cummins, J. (2000). Language, power, and pedagogy: Bilingual children in the crossfire. Clevedon: Multilingual Matters Ltd.

Goldschmidt, M. M., \& Miller, C. Z. (2005). Beyond the academic needs of generation 1.5. Research and Teaching in Developmental Education, 21(2), 10-19.

Heller, M. (1987). The role of language in the formation of ethnic identity. In J. S. Phinney \& M. J. Rotheram (Eds.), Children's ethnic socialization: Pluralism and development (pp. 180-200). Newbury Park: Sage Publications.

Huss, L. (2008). Researching language loss and revitalization. In N. Hornberger (Ed.), Encyclopaedia of language and education (pp. 3274-3286). New York: Springer.

Jenkins, R. (2014). Social identity. London: Routledge.

Kamerāde, D. (2017). Future loss: Global economic crisis, austerity management and child and youth migration (Under Review).

Kārkliṇa \& Kamerāde. (2016). Nenāc manā istabāa, es nesaprotu latviski. Latvijas emigrantu bērnu valodas un identitātes veidošanās [Don't enter my room, I don't understand Latvian. Formation of the language and identity of the Latvian emigrants' children]. https://migracija. lv/post/144653065413/nen\%C4\%81c-man\%C4\%81-istab\%C4\%81-es-nesaprotu-latviski. Accessed 30 July 2016.

Kasnitz, P., Mollenkopf, J. H., Waters, M. C., \& Holdaway, J. (2009). Inheriting the city: The children of immigrants come of age. New York: Russell Sage Foundation.

Ķešāne, I. (2011). Emigrācija un identitāte [Emigration and identity]. In B. Zepa \& E. Kḷave (Eds.), Latvija. Pārskats par tautas attīstību 2010./2011. Nacionālā identitāte, mobilitāte un rīcībspēja (Latvia. Human development report 2010/2011. National identity, mobility and capability) (pp. 64-70). Rīga: Latvijas Universitātes Akadēmiskais apgāds.

Kim, J., \& Duff, P. A. (2012). The language socialization and identity negotiations of generation 1.5 Korean-Canadian University students. TESL Canada Journal, 29, 81.

Kivisto, P. (2001). Theorizing transnational immigration: A critical review of current efforts. Ethnic and Racial Studies, 24(4), 549-577.

Liang, X. (2006). Identity and language functions: High school Chinese immigrant students' code-switching dilemmas in ESL classes. Journal of Language, Identity, and Education, 5(2), $143-167$.

Lulle, A. (2011). Home redefined: Latvians in Guernsey. In I. Garda-Rozenberga \& M. Zirnīte (Eds.), Oral history: Migration and local identities (pp. 23-33). Rīga: LU FSI. 
Lulle, A., \& Klave, E. (Eds.). (2015). Possibilities of development: Education of Latvian diaspora youth and children. Riga: University of Latvia press.

Margeviča-Grinberga, I. (2015). Valodu apguves teorētiskie un praktiskie aspekti: uz pētījumiem balstîts skatījums [Theoretical and practical aspects in language learning: Research based view]. In A. Lulle \& E. Klave (Eds.), Possibilities of development: Education of Latvian diaspora youth and children (pp. 163-184). Riga: University of Latvia press.

McKay, S. L., \& Wong, S. C. (1996). Multiple discourses, multiple identities: Investment and agency in second-language learning among Chinese adolescent immigrant students. Harvard Educational Review, 66(3), 577-609.

NIPSIPP. (2015). Nacionālās identitātes, pilsoniskās sabiedrības un integrācijas politikas pamatnostädnes 2012.-2018. gadam [National identity, civil society and integration policy guidelines 2012-2018]. http://polsis.mk.gov.lv/docSearch.do?searchtype=ows\&clearnav=t rue. Accessed 23 Jul 2015.

Norton, B. (1997). Language, identity, and the ownership of English. TESOL Quarterly, 31(3), 409-429.

Norton, B. (2000). Identity and language learning: Gender, ethnicity and educational change. Harlow: Longman.

Norton, B. (2013). Identity and language learning: Extending the conversation. London: Routledge.

OECD. (2014). International migration outlook 2014. Paris: OECD Publishing.

ONS. (2015). CT0436 - National identity by age: Dual national identity. http://webarchive. nationalarchives.gov.uk/20160110200016/http://www.ons.gov.uk/ons/about-ons/businesstransparency/freedom-of-information/what-can-i-request/published-ad-hoc-data/census/ethni city\%2D\%2Didentity\%2D\%2Dlanguage-and-religion\%2D\%2Deilr-/index.html. Accessed 6 May 2017.

Parpola, S. (2004). National and ethnic identity in the Neo-Assyrian empire and Assyrian identity in post-empire times. Journal of Assyrian Academic Studies, 18(2), 5-22.

Pavlenko, A. (2011). Thinking and speaking in two languages: Overview of the field. In A. Pavlenko (Ed.), Thinking and speaking in two languages (pp. 237-257). Clevedon: Multilingual matters.

Phinney, J. S., \& Rotheram, M. J. (1987). Children's ethnic socialization: Themes and implications. In J. S. Phinney \& M. J. Rotheram (Eds.), Children's ethnic socialization: Pluralism and development (pp. 274-292). Newbury Park: Sage Publications.

Phinney, J. S., Romero, I., Nava, M., \& Huang, D. (2001). The role of language, parents, and peers in ethnic identity among adolescents in immigrant families. Journal of Youth and Adolescence, $30(2), 135-153$.

Portes, A., Guarnizo, L. E., \& Landolt, P. (1999). The study of transnationalism: Pitfalls and promise of an emergent research field. Ethnic and Racial Studies, 22(2), 217-237.

Roberge, M. M. (2003). Generation 1.5 immigrant students: What special experiences, characteristics and educational needs do they bring to our English classes. Paper presented at the Teachers of english to speakers of other languages convention, Baltimore.

Rosenthal, D. A. (1987). Ethnic identity development in adolescents. In J. S. Phinney \& M. J. Rotheram (Eds.), Children's ethnic socialization: Pluralism and development (pp. 156-179). Newbury Park: Sage.

Rumbaut, R. G. (1976). The one-and-half generation: Crisis, commitment, identity. In P. I. Rose (Ed.), The dispossessed: An anatomy of exile (pp. 331-355). Amherst: University of Massachusetts Press.

Rumbaut, R. G., \& Ima, K. (1988). The adaptation of Southeast Asian refugee youth: A comparative study. http://eric.ed.gov/ERICWebPortal/contentdelivery/servlet/ ERICServlet?accno=ED299372. Accessed 27 May 2015.

Singhal, M. (2004). Academic writing and generation 1.5: Pedagogical goals and instructional issues in the college composition classroom. The Reading Matrix, 4(3), 1-12.

Strand, S., Malnberg, L., \& Hall, J. (2015). English as an additional language (EAL) and educational achievement in England: An analysis of the national pupil database. Oxford: University of Oxford, Department of Education. 
Strauss, A. L., \& Corbin, J. M. (1998). Basics of qualitative research: Techniques and procedures for developing grounded theory (2nd ed.). Thousand Oaks: Sage.

Šupule, I. (2012). The construction of national and ethnic identity in online discussions on referenda initiatives in Latvia. Baltic Journal of European Studies, 2(1/11), 119-137.

Trapenciere, I. (2012). Euro-orphans or nobody's children - the door open to exclusion. Paper presented at the Second ISA Forum of Sociology, Buenos Aires.

Urry, J. (2000). Sociology beyond societies: Mobilities for the twenty-first century. New York: Routledge.

Vertovec, S. (2009). Transnationalism. New York: Routledge.

Vertovec, S. (2010). Conceiving and researching transnationalism. In M. Martiniello \& J. Rath (Eds.), Selected studies in international migration and immigrant incorporation (pp. 91-110). Amsterdam: Amsterdam University Press.

Westin, C. (2010). Identity and inter-ethnic relations. In C. Westin, J. Bastos, \& J. Dahinden (Eds.), Identity processes and dynamics in multi-ethnic Europe (pp. 9-52). Amsterdam: Amsterdam University press.

Yang, J. (2010). Lost in the puzzles. In M. Cox, J. Jordan, C. Ortmeier-Hooper, \& G. G. Schwartz (Eds.), Reinventing identities in second language writing (pp. 51-53). Urbana: NCTE.

Yuzefova, O. (2012). National identity perceptions and the experiences of 1.5 generation youth with English learning and first language loss. London: The University of Western Ontario.

Open Access This chapter is licensed under the terms of the Creative Commons Attribution 4.0 International License (http://creativecommons.org/licenses/by/4.0/), which permits use, sharing, adaptation, distribution and reproduction in any medium or format, as long as you give appropriate credit to the original author(s) and the source, provide a link to the Creative Commons licence and indicate if changes were made.

The images or other third party material in this chapter are included in the chapter's Creative Commons licence, unless indicated otherwise in a credit line to the material. If material is not included in the chapter's Creative Commons licence and your intended use is not permitted by statutory regulation or exceeds the permitted use, you will need to obtain permission directly from the copyright holder.

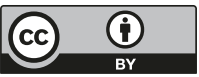

